\section{Articles}

5 Eternal Guests, Mimics, and

Dönme: The Place of German and

Turkish Jews in Modern Turkey

Kader Konuk

31 Retrieving the Dignity of a

Cosmopolitan City: Contested Perspectives on Rights, Culture and Ethnicity in Mardin

Zerrin Ozlem Biner

59 The Politics of Urban Regeneration:

The Case of the Fener and Balat Initiative

Dikmen Bezmez

87 Labor Transformation through the

Prism of the Household: Evidence From

The Turkish Tourism Industry

Aslihan Aykaç

115 Markets and Fields: An Ethnography

of Cotton Production and Exchange in a

Turkish Village

Koray Çalışkan

147 Health as a Social Agent in Ottoman Patronage and Authority

Miri Shefer Mossensohn

177 From Left Populism to Conservative Republicanism: Left Kemalists'

Regression from Modernist Optimism Yüksel Taşkın

\section{Commentary}

203 Dilemmas of Critique

Çă̆lar Keyder

\section{Review Article}

211 A Call for an Environmental History of the Ottoman Empire and Turkey:

Reflections on the Fourth ESEH

Conference

Selçuk Dursun

\section{Book Reviews}

223 Behzad Yaghmaian. Embracing the Infidel: Stories of Muslim Migrants on the Journey West. New York: Delacorte Press Bantam Dell, 2005.

Kristen Biehl

228 Carter V. Findley. The Turks in World History, Oxford: Oxford University

Press, 2005.

Yonca Köksal

231 Ibrahim Sirkeci. The Environment of Insecurity in Turkey and the Emigration of Turkish Kurds to Germany. Lewiston: Edwin Mellen Press, 2006.

Turgay Ünalan

\section{Correspondence}

235 A Reply to Ahmet T. Kuru

Elise Massicard

\title{
ISBN 978-9944-483-15-5
}

